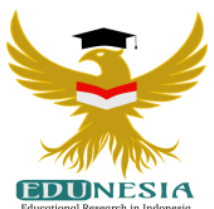

\title{
Peningkatan Kinerja Guru Dalam Menerapkan Model Pembelajaran Contextual Teaching And Learning (CTL) Melalui Kegiatan Supervisi Klinis Pada MTsS Harapan Kab. Nagan Raya Tahun Pelajaran 2018/2019
}

\author{
Usman \\ Supervisi Kelas, MTsS Harapan Kab, Nagan Raya, Indonesia \\ Corresponding Email: usman.guru1969@gmail.com, Phone Number : 0852 xxxx xxxx
}

\author{
Article History: \\ Received: Okt 09, 2020 \\ Revised: Okt 17, 2020 \\ Accepted: Okt 18, 2020 \\ Published: Nov 01, 2020
}

\section{Keywords:}

clinical supervision , contextual teaching and learning, performance.

\section{Kata Kunci:}

contextual teaching and learning, kinerja, supervisi klinis

\section{How to cite:}

Usman. (2020). Peningkatan Kinerja Guru Dalam Menerapkan Model Pembelajaran Contextual Teaching And Learning (CTL) Melalui Kegiatan Supervisi Klinis Pada MTsS Harapan Kab. Nagan Raya Tahun Pelajaran 2018/2019. Edunesia : Jurnal Ilmiah Pendidikan, 1 (3): 107-115

This is an open access article under the $C C-B Y-N C-N D$ license (c) $\$ \circledast$

\begin{abstract}
This study aims to determine the improvement of teachers' performance in learning using the CTL learning model through clinical supervision at MTsS Harapan Kab Nagan Raya. This research is a school action research (School Action Research), the research was conducted and carried out in 2 cycles with 2 meetings in each cycle. The research stages were planning, implementing, observing and reflecting. The research subjects were 6 class teachers at MTsS Harapan in the 2018/2019 academic year. The data was obtained by having an observation and documentation. This school action research used 3 (three) assessment instruments, they were the Assessment of The Lesson Plan, the Learning Planning Ability, and the implementation of the lesson plan, Evaluation, and Follow Up. Data validation used triangulation data and source. The data analysis used a qualitative descriptive technique. Based on the data analysis, the research results showed that the implementation of classroom supervision by the principal has proven successful in improving the performance of teachers in Islamic Studies, Indonesian Language and Mathematics at MTsS Harapan Kab Nagan Raya, in managing the learning process by applying the contextual teaching and learning (CTL) model. The improvement of the results of the observations was made in 3 aspects of the assessment. In the Lesson Plan Assessment, it was increased from 54.46 to 75.60 and 94.35, while the aspect of assessing the ability to plan learning increased from 54.63 to 70.83 and 87.96 and the aspect of the ability to carry out learning, evaluation, action continued from 55.77 to 68.91 and 81.73 at the end of the second cycle.
\end{abstract}

Abstrak: Penelitian ini bertujuan untuk mengetahui peningkatan kinerja guru dalam pembelajaran menggunakan model pembelajaran CTL melalui supervisi klinis di MTsS Harapan Kab Nagan Raya. Penelitian ini merupakan penelitian tindakan sekolah (School Action Research), penelitian dilakukan dan dilaksanakan dalam 2 siklus dengan 2 kali pertemuan pada setiap siklusnya. Tahapan penelitian yaitu perencanaan, pelaksanaan, observasi dan refleksi. Subjek penelitian adalah guru kelas di MTsS Harapan pada Tahun Pelajaran 2018/2019 yang berjumlah 6 orang. Teknik pengumpulan data dengan kegiatan observasi dan dokumentasi. Alat pengumpul data pada kegiatan penelitian tindakan sekolah ini menggunakan 3 (tiga) instrumen penilaian, yaitu Penilaian Rencana Pelaksanaan Pembelajaran (RPP), Instrumen Penilaian Kemampuan Merencanakan Pembelajaran, dan Instrumen Penilaian Kemampuan Melaksanakan Pembelajaran, Evaluasi, Tindak Lanjut. Validasi data menggunakan triangulasi data dan sumber. Analisis data menggunakan teknik deskriptif kualitatif. Berdasarkan analisis data hasil penelitian menunjukkan bahwa pelaksanaan supervisi kelas oleh kepala sekolah terbukti berhasil meningkatkan kinerja guru mata pelajaran PAI, Bahasa Indonesia dan Matematika di MTsS Harapan Kab Nagan Raya, dalam mengelola proses pembelajaran dengan menerapkan model pembelajaran contextual teaching and learning (CTL) dibuktikan dengan peningkatan hasil observasi yang dilakukan pada 3 apsek penilaian. Pada aspek penilaian Rencana Pelaksanaan Pembelajaran (RPP) meningkat dari 54,46 menjadi 75,60 dan 94,35 sedangkan aspek penilaian kemampuan merencanakan pembelajaran meningkat dari 54,63 menjadi 70,83 dan 87,96 dan aspek kemampuan melaksanakan pembelajaran, evaluasi, tindak lanjut dari 55,77 menjadi 68,91 dan 81,73 pada akhir siklus kedua. 


\section{A. Pendahuluan}

Kompetensi guru merupakan faktor pertama yang dapat mempengaruhi keberhasilan pembelajaran. Guru yang memilikikemampuan tinggi akan bersikap kreatif dan inovatif yang selamanya akan mencoba dan mencoba menerapkan berbagai penemuan baru yang dianggap lebih baik untuk pembelajaran siswa. Secara umum, kompetensi guru dapat diklasifikasi menjadi kompetensi pedagogik, kompetensi profesional, kompotensi personal, dan kompetensi sosial yang diperoleh melalui pendidikan profesi (Ilfiandra, 2016)

Suatu asumsi bahwa peningkatan mutu pembelajaran di sekolah dapat dicapai melalui peningkatan mutu sumber daya manusia (guru dan tenaga kependidikan lainnya), walaupun diakui bahwa komponen-komponen lain turut memberikan kontribusi dalam peningkatan mutu pembelajaran. Peningkatan sumber daya menusia telah banyak dilakukan pemerintah, terutama peningkatan kompetensi guru. Usaha ini berupa peningkatan kompetensi melalui pendidikan dan pelatihan, workshop atau bentuk lainnya. Dalam usaha untuk memperbaiki dan meningkatkan proses pembelajaran yang dilakukan oleh guru, kepala sekolah bertugas menyelenggarakan serta melaksanakan kegiatan supervisi. Tugas ini cukup penting karena melalui peran supervisor, kepala sekolah dapat memberi bantuan, bimbingan, ataupun layanan kepada guru dalam menjalankan tugas ataupun dalam memecahkan permasalahan yang dihadapi pada saat proses pembelajaran (Suradi, 2018).

Untuk melaksanakan supervisi akademik secara efektif diperlukan keterampilan konseptual, interpersonal dan teknikal (Glickman dalam Masnun, 2017). Oleh sebab itu, setiap Kepala sekolah harus memiliki keterampilan teknikal berupa kemampuan menerapkan teknik-teknik supervisi yang tepat dalam melaksanakan supervisi akademik. Teknik-teknik supervisi akademik meliputi dua macam, yaitu: individual dan kelompok. Supervisi akademik harus secara langsung mempengaruhi keadaan lingkungan perilaku guru dalam mengelola kelas pada proses pembelajaran dimana guru secara langsung maupun tidak langsung mengubah mindset mereka dalam menyampaikan materi pembelajaran pada kegiatan pendahuluan, kegiatan inti, maupun kegiatan penutup. Kompetensi guru yang mampu mengubah mindsetnya terlihat pada tahap-tahap pembelajaran (Usman, 2018). Menurut Zulfikar (2017) pelaksanaan supervisi akademik oleh kepala sekolah dapat meningkatkan proses pembelajaran jika dilakukan sesuai dengan prinsip-prinsip yang berlaku. Oleh karena itu, kepala sekolah sebagai supervisor dituntut untuk mampu melakukan supervisi akademik bagi guru-guru dalam meningkatkan proses pembelajaran.

Tujuan supervisi akademik adalah mengembangkan profesionalisme, memotivasi guru, dan meningka tkan kualitas pembelajaran (Kemdiknas, 2011:6). Beberapa prinsip supervisi akademik yang harus dijadikan pedoman kepala sekolah dalam melaksanakan tugas sebagai supervisor adalah: praktis, sistematis, objektif, realistis, antisipatif, konstruktif, kooperatif, kekeluargaan, demokratis, aktif, humanis, berkesinambungan, terpadu, komprehensif, (Kemdikbud, 2012). Melalui supervisi, para guru sebagai pelaku utama dalam penyelenggaraan sistem pendidikan dapat dibantu pertumbuhan dan perkembangan profesinya bagi pencapaian tujuan pembelajaran (Istianah, 2019).

Menurut Wahidin (2018) pembelajaran yang dirancang oleh guru sebaiknya mempunyai mekanisme dan harus menciptakan lingkungan yang mendukung peroses pembelajaran sehingga pada diri peserta didik terjadi proses pembelajaran dengan baik. Dalam aspek perencanaan misalnya, guru dituntut untuk mampu mendesain perencanaan yang memungkinkan secara terbuka siswa dapat belajar sesuai dengan minat dan 
bakatnya., seperti kemampuan merumuskan tujuan pembelajaran, kemampuan menyusun dan menyajikan materi atau pengalaman belajar siswa, kemampuan untuk merancang desian pembelajaran yang tepat sesuai dengan tujuan yang akan dicapai, kemampuan menentukan dan memanfaatkan media dan sumber belajar, serta kemampuan menentukan alat evaluasi yang tepat untuk mengukur keberhasilan proses pembelajaran.

Peranan guru sangat menentukan karena kedudukannya sebagai pemimpin pendidikan di antara peserta didik dalam suatu kelas. Guru bertanggung jawab untuk mengatur, mengarahkan dan menciptakan suasana yang dapat mendorong peserta didik untuk melaksanakan kegiatan-kegiatan di dalam kelas. Untuk menunjang tugas tersebut maka guru perlu ditunjang dengan kemampuan profesional yang memadai. Guru yang profesional adalah guru yang menguasai kurikulum, menguasai materi pelajaran, menguasai model-model dan atau metode-metode pembelajaran, menguasai penggunaan media pembelajaran, menguasai teknik penilaian pembelajaran, dan komitmen terhadap tugas. Dengan demikian diharapkan proses pembelajaran yang dilaksanakan guru, dapat dicapai tanpa pemborosan waktu, tenaga, material, finansial, dan bahkan pemikiran sehingga pada gilirannya tujuan sekolah dapat dicapai secara efektif dan efisien.

Pembelajaran yang diberikan guru amat kurang sekali variasinya, dan dengan sedikit kekecualian, pola yang sama telah menjadi standar di ulang-ulang sepanjang jam pelajaran sekolah. Kadang-kadang guru mulai mengajar dengan hanya mendiktekan saja pelajarannya dan jika masih ada waktu baru memberikan penjelasan sekedarnya tidak mencerminkan pembelajaran CTL apa lagi tanpa variasi dengan penggunaan media yang sesuai maupun sumber-sumber belajar yang memadai. Apabila kebiasaan seperti itu tetap dipraktekkan oleh para guru di kelas selama proses pembelajaran, maka dapat dipastikan bahwa peningkatan mutu pendidikan akan sulit dicapai. Menurut Jamaluddin (2015) model pembelajaran CTL merupakan proses pembelajaran yang bertujuan untuk membantu siswa dalam berkarya, mengaplikasikan pengetahuan dengan menghubungkan pelajaran dalam konteks kehidupan nyata.

Guru dikatakan tidak saja semata-mata sebagai pengajar (transfer of knowledge), tetapi pendidik (transfer of value) dan sekaligus sebagai pembimbing yang memberikan penghargaan dan menuntun murid dalam belajar. Para pakar pendidikan seringkali menegaskan bahwa guru adalah sumber daya manusia yang sangat menentukan keberhasilan program pendidikan. Pada umumnya kegiatan guru hanya mentrasfer pengetahuan atau pengalamannya dengan sedikit memberi kesempatan siswa untuk berdiskusi dan diakhiri dengan pemberian tugas atau latihan tanpa menggunakan media dan sumber belajar yang memadai.

Setelah ditelusuri melalui pengamatan atau dialog peneliti dengan beberapa guru di MTsS Harapan Kab Nagan Raya, faktor penyebabnya adalah kebanyakan guru-guru kurang menguasai pembelajaran CTL dan keterampilan penggunaan media serta sumber belajar yang ada sehingga pembelajaran yang mereka laksanakan masih didominasi dengan cara mentrasfer dari pada menciptakan pembelajaran yang memberi kesempatan siswa untuk mengkonstruksi pengetahuannya.

Berdasarkan uraian di atas, tampak bahwa model dan strategi pembelajaran yang tepat akan berdampak positif bagi siswa. Kenyataan yang ada di sekolah tempat peneliti bertugas sebagai kepala sekolah menunjukkan hal yang terbalik. Dari hasil supervisi yang peneliti lakukan menunjukkan bahwa 90\% guru di MTsS Harapan Kab Nagan Raya masih dominan belum menggunakan strategi pembelajaran yang tepat sesuai dengan karaketristik siswa dan situasi kelas. Bila ditelusuri lebih lanjut, faktor yang meyebabkan guru belum 
mampu melaksanakan strategi pembelajaran dengan tepat karena kinerja menyusun strategi model pembelajaran CTL belum optimal, bahkan ada yang tidak membuat. Penerapan model CTL pembelajaran sangat penting, karena perencanaan yang baik berpengaruh terhadap hasil belajar siswa. Oleh karena itu diperlukan adanya perubahan paradigma dalam melaksanakan pembelajaran yang semula guru berpikir bagaimana mengajar menjadi berpikir bagaimana siswa belajar.

\section{B. Metode}

Penelitian ini mengambil bentuk penelitian tindakan sekolah (PTS) yaitu peningkatan kinerja guru melalui kunjungan kelas dalam rangka mengimplementasikan standar proses, yang terdiri dari 3 siklus dan masing masing siklus terdiri dari 4 tahap yaitu : (1) tahap perencanaan program tindakan, (2) pelaksanaan program tindakan, (3) pengamatan program, (4) refleksi. Langkah-langkah PTS yaitu: perencanaan, pelaksanaan, pengamatan, dan refleksi.

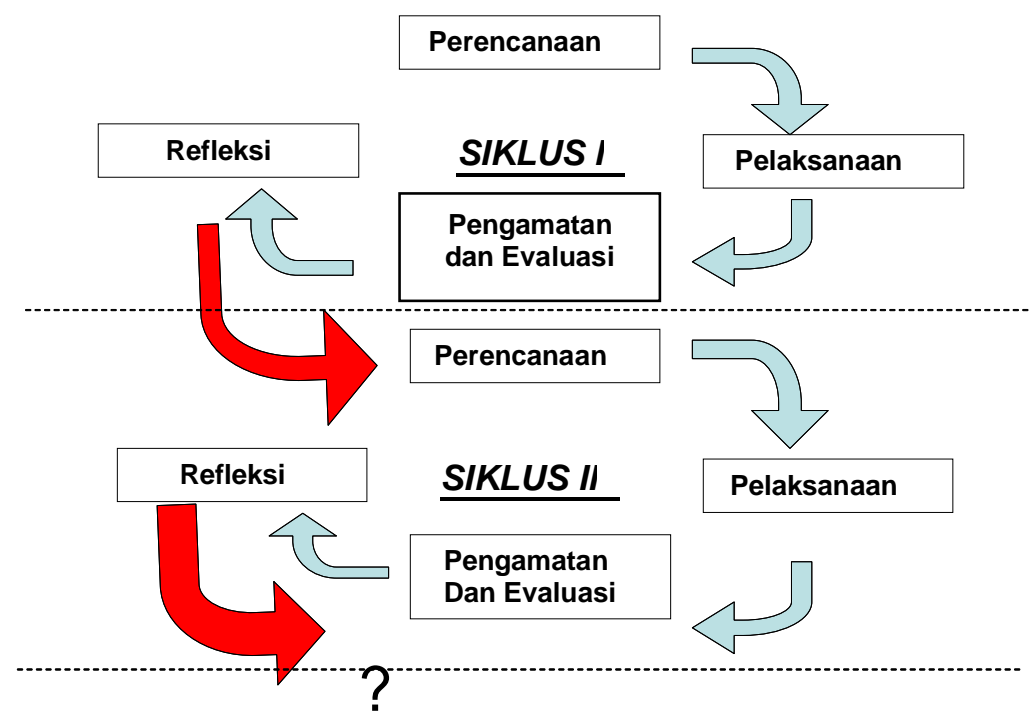

Gambar 1. Langkah-langkah PTS

\section{Hasil dan Pembahasan}

Keberhasilan tindakan ini disebabkan oleh pemahaman menyeluruh tentang peningkatan kinerja guru mata pelajaran PAI, Bahasa Indonesia, dan Matematika, dalam menerapkan metode pembelajaran bermain peran. Dengan kinerja yang baik, maka pelaksanaan supervisi kelas yang bersifat instruktif kepada para guru terutama guru yang mengajar kelas dapat mengoptimalkan pemahaman guru terhadap metode mengajar yang inovatif melalui pembinaan secara intensif dengan menerapkan salah satu jenis metode mengajar yaitu model pembelajaran contextual teaching and learning (CTL) sebagai sumber belajarnya. Pelaksanaan supervisi kelas sebagai wujud pembinaan dalam rangka menerapkan variasi penggunaan metode-metode dalam pembelajaran. Mengingat setiap guru mata pelajaran PAI, Bahasa Indonesia, dan Matematika, mempunyai permasalahan tentang mata pelajaran maupun metode mengajar menurut jenjang kelas masing-masing, maka pelaksanaan supervisi kelas mutlak dilaksanakan. Kesesuaian persepsi tentang pentingnya variasi penerapan metode-metode pembelajaran menjadi kunci pokok keberhasilan pelaksanaan kegiatan supervisi yang dilakukan oleh peneliti yang 
berkolaborasi dengan guru mata pelajaran PAI, Bahasa Indonesia, dan Matematika, dengan didukung oleh semua sarana dan prasarana yang ada di sekolah.

Dalam bentuk tabel, peningkatan kinerja guru mata pelajaran PAI, Bahasa Indonesia, dan Matematika, dalam menerapkan metode pembelajaran khususnya model pembelajaran contextual teaching and learning (CTL) pada kondisi awal sampai dengan pelaksanaan siklus kedua sebagaimana dijelaskan tabel 1.

Tabel 1.

Analisis Hasil Observasi Penilaian Rencana Pelaksanaan Pembelajaran (RPP) pada Kondisi Awal, Siklus I dan II

\begin{tabular}{ccccc|}
\hline \multirow{2}{*}{ No } & \multirow{2}{*}{ Siklus } & \multicolumn{3}{c}{ Rerata Hasil Penilaian } \\
\cline { 3 - 5 } & & Riil & Nilai & Kriteria \\
\hline 1 & Awal & 30,50 & 54,46 & K \\
\hline 2 & Siklus I & 42,33 & 75,60 & C \\
\hline 3 & Siklus II & 52,83 & 94,35 & B \\
\hline
\end{tabular}

Dalam bentuk diagram batang sebagaimana dijelaskan pada gambar 2 .

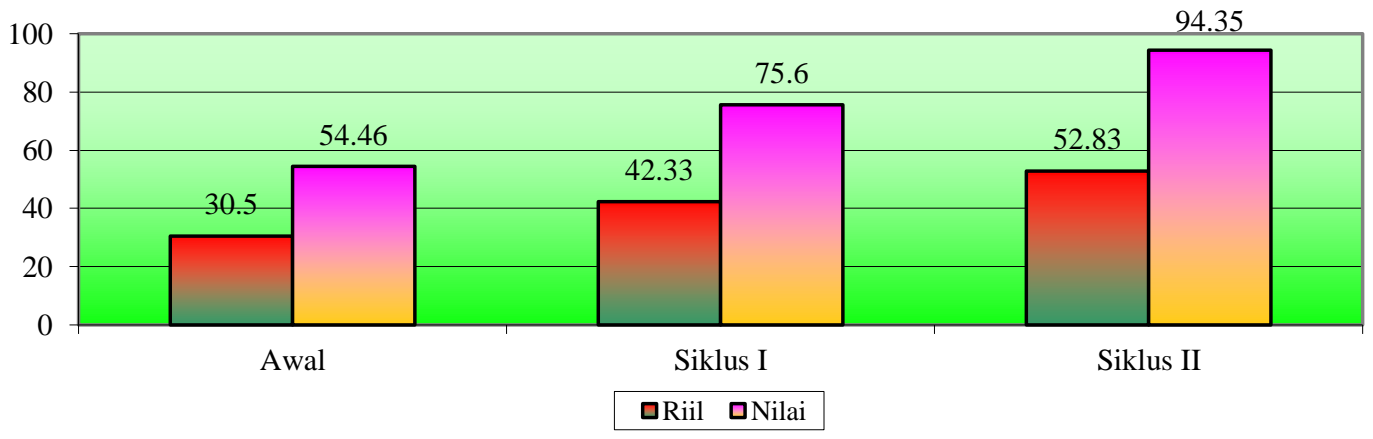

Gambar 2.

Analisis Hasil Observasi Penilaian Rencana Pelaksanaan Pembelajaran (RPP) pada Kondisi Awal, Siklus I dan Siklus II

Penjelasan mengenai peningkatan kinerja guru mata pelajaran PAI, Bahasa Indonesia, dan Matematika, dalam Kemampuan Merencanakan Pembelajaran sebagaimana dijelaskan di tabel 2.

Tabel 2

Analisis Hasil Observasi Penilaian Kemampuan Merencanakan Pembelajaran pada Kondisi Awal, Siklus I dan Siklus II

\begin{tabular}{ccccc}
\hline \multirow{2}{*}{ No } & \multirow{2}{*}{ Siklus } & \multicolumn{3}{c}{ Rerata Hasil Penilaian } \\
\cline { 3 - 5 } & & Riil & Nilai & Kriteria \\
\hline 1 & Awal & 19,33 & 54,63 & K \\
\hline 2 & Siklus I & 25,50 & 70,83 & $\mathrm{C}$ \\
\hline 3 & Siklus II & 31,67 & 87,96 & B \\
\hline
\end{tabular}


Dalam bentuk diagram batang sebagaimana dijelaskan pada gambar 3 .

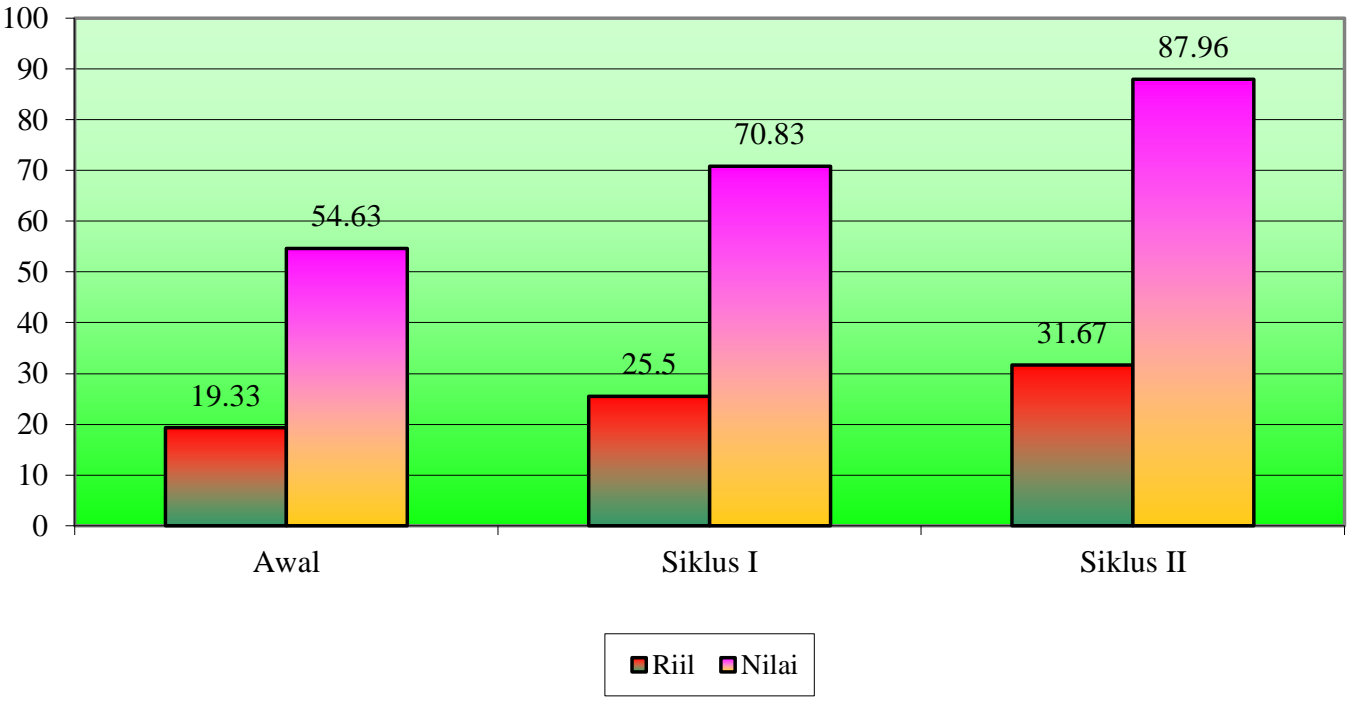

\section{Gambar 3.}

Analisis Hasil Observasi Penilaian Kemampuan Merencanakan Pembelajaran pada Kondisi Awal, Siklus I dan Siklus II

Penjelasan mengenai peningkatan kinerja guru mata pelajaran PAI, Bahasa Indonesia, dan Matematika, dalam kemampuan melaksanakan pembelajaran, evaluasi, tindak lanjut sebagaimana dijelaskan di tabel 3.

Tabel 3.

Analisis Hasil Observasi Penilaian Kemampuan Melaksanakan Pembelajaran, Evaluasi, Tindak Lanjut pada Kondisi Awal, Siklus I dan Siklus II

\begin{tabular}{ccccc|}
\hline \multirow{2}{*}{ No } & \multirow{2}{*}{ Siklus } & \multicolumn{3}{c}{ Rerata Hasil Penilaian } \\
\cline { 3 - 5 } & & Riil & Nilai & Kriteria \\
\hline 1 & Awal & 29,00 & 55,77 & $\mathrm{~K}$ \\
\hline 2 & Siklus I & 35,83 & 68,91 & $\mathrm{C}$ \\
\hline 3 & Siklus II & 42,50 & 81,73 & $\mathrm{~B}$ \\
\hline
\end{tabular}

Dalam bentuk diagram batang sebagaimana dijelaskan pada gambar 4 .

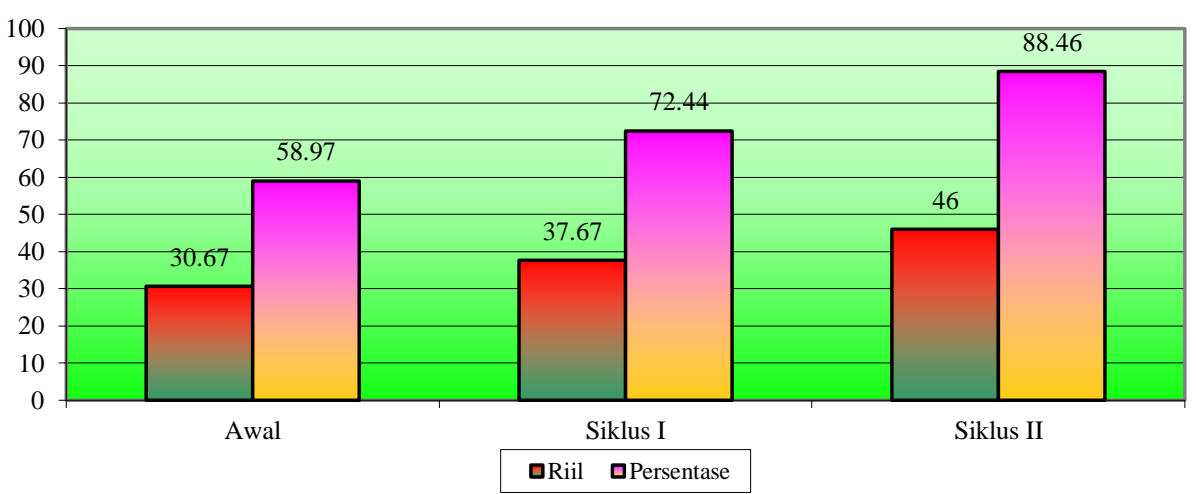

Gambar 4. Analisis Hasil Observasi Penilaian Kemampuan Melaksanakan Pembelajaran, Evaluasi, Tindak Lanjut pada Kondisi Awal, Siklus I dan Siklus II 
Dari paparan di atas menunjukkan bahwa pelaksanaan supervisi kelas terbukti dapat meningkatkan kinerja guru dalam menerapkan model pembelajaran contextual teaching and learning (CTL) dalam pembelajaran khususnya di kelas . Dari uraian dan penjelasan serta analisis data yang diperoleh dapat disimpulkan bahwa :

1. Pentingnya supervisi kelas oleh pengawas sekolah MTsS Harapan, yang di dalamnya bermuatan daya upaya yang akurat guna meningkatkan kemampuan guru dalam mengelola proses pembelajaran;

2. Kemampuan pengawas sekolah dalam mendayagunakan antarkomponen penting terkait dengan model pembelajaran contextual teaching and learning (CTL), merupakan modalitas mendasar bagi berlangsungnya proses transformasi kemampuan ini kepada guru MTsS Harapan.

3. Meningkatnya kemampuan guru MTsS Harapan dalam mengelola proses pembelajaran yang berlandaskan pada model pembelajaran contextual teaching and learning (CTL) yang diterapkan, tidak terlepas dari meningkatnya kesadaran pengawas sekolah untuk luruh di dalamnya secara bertanggung jawab, yang diaktualisasikan pada tindakan-tindakan nyata yang bersifat preventif (mencegah), membimbing, mengarahkan, dan menjadi rekan sejawat nan bijak dalam memenuhi setiap kebutuhan guru dan siswa dalam rangka mencapai suatu perubahan yang diinginkan.

4. Dengan berkembangnya perilaku-perilaku baik seperti di atas, maka terjadilah suatu perubahan ke arah yang dinginkan oleh masing-masing. Meski untuk berubah itu beresiko, baik pengawas sekolah, pengawas sekolah maupun guru-guru MTsS Harapan, tetap mengambil strategi ini. Ketimbang tidak berubah sama sekali, mereka merasa yakin jauh akan lebih beresiko. Kepiawaian pengawas sekolah dalam memilih tingkat resiko, baik secara ekonomis maupun material, dapat mencegah hal-hal yang tidak diinginkan, seperti pemborosan, lebih meluangkan waktu, tenaga, dan pemikiran.

5. Termasuk masalah yang kompleks dan tidak mudah dalam menyelesaikan kasus pengelolaan proses pembelajaran. Terlebih lagi ketika masalah itu berkaitan dengan kualitas pengelolaan proses pembelajaran. Sudah menjadi rumus yang baku untuk bisa berlangsungnya hal itu diperlukan segala sesuatunya yang berkualitas, baik SDM guru, material, maupun proses berlangsungnya. Dalam rangka mengupayakan kualitas ini, peran serta pengawas sekolah akan sangat mewarnai peran serta guru dan siswa. Supervisi merupakan bagian integral dari kemampuan profesional pengawas sekolah yang berkualitas. Tanpa berkemampuan melakukan supervisi, mustahil pengawas sekolah MTsS Harapan, berhasil meningkatkan kualitas kemampuan guru dalam mengelola proses pembelajaran dengan model pembelajaran contextual teaching and learning (CTL).

\section{Kesimpulan}

Dari pelaksanaan kegiatan penelitian tindakan sekolah yang dilaksanakan dalam 2 siklus, maka dapat disimpulkan bahwa :

1. Penerapan supervisi kelas oleh kepala sekolah terbukti berhasil meningkatkan kinerja guru mata pelajaran PAI, Bahasa Indonesia dan Matematika di MTsS Harapan Kab. Nagan Raya, dalam mengelola proses pembelajaran dengan menerapkan model pembelajaran contextual teaching and learning (CTL).Dengan 
meningkatnya kinerja guru mata pelajaran PAI, Bahasa Indonesia dan Matematika di MTsS Harapan dalam mengelola proses pembelajaran, selain proses belajar siswa lebih bermakna juga hasil belajarnya pun turut meningkat.

2. Peningkatan kinerja guru mata pelajaran PAI, Bahasa Indonesia dan Matematika di MTsS Harapan Kab. Nagan Raya dalam mengelola pembelajaran dengan menerapkan model pembelajaran contextual teaching and learning (CTL) dibuktikan dengan peningkatan hasil observasi yang dilakukan pada 3 apsek penilaian. Pada aspek penilaian Rencana Pelaksanaan Pembelajaran (RPP) meningkat dari 54,46 menjadi 75,60 dan 94,35 sedangkan aspek penilaian kemampuan merencanakan pembelajaran meningkat dari 54,63 menjadi 70,83 dan 87,96 dan aspek kemampuan melaksanakan pembelajaran, evaluasi, tindak lanjut dari 55,77 menjadi 68,91 dan 81,73 pada akhir siklus kedua.

\section{Daftar Pustaka}

Ilfiandra, I., Suherman, U., Akhmad, S. N., Budiamin, A., \& Setiawati, S. (2016). Pelatihan dan Pendampingan Penulisan Karya Tulis Ilmiah Bagi Guru SD. Jurnal Pengabdian Pada Masyarakat, 1(1), 70-81.

Istianah, I. (2019). Implementasi Program Supervisi Akademik Kepala Sekolah Dalam Meningkatkan Profesionalisme Guru di SMAN 1 Cikarang Utara dan MAN Kabupaten Bekasi. Rasi Pendidikan, Volume 26 Issue 1, April 2019 H, 26(1).

Jamaluddin S., Iqbal, M., \& Asto, I.G.P. (2015). Pengaruh Model Pembelajaran CTL (Contextual Teaching and Learning) terhadap Hasil Belajar Siswa pada Kompetensi Dasar Menerapkan Macam -Macam Gerbang Dasar Rangkaian Logika di SMK Negeri 7 Surabaya. Jurnal Pendidikan Teknik Elektro. Volume 04 Nomor 01 Hal. 73-79.

Mendiknas. (2011). Supervisi akademik materi pelatihan penguatan kemampuan kepala sekolah.Jakarta: PPTK

Mendikbud. (2012). Pedoman penilaian kinerja kepala sekolah. Jakarta: Badan Pengembangan Sumber Daya Manusia Pendidikan dan Kebudayaan dan Penjaminan Mutu Pendidikan Pusat Pengembangan Tenaga Ke Pendidikan.

Masnun, B. (2017). Mengefektifkan Supervisi Akademik Dalam Upaya Meningkatkan Kompetensi Guru Kelas Dalam Proses Pembelajaran Semester Satu Tahun Pelajaran 2016/2017 SD Negeri 27 Ampenan. JIME, 3(1).

Suradi, A. (2018). Supervisi Akademik Kepala Sekolah Terhadap Kinerja Guru Pendidikan Agama Islam Di Sekolah Dasar Negeri 79 Kota Bengkulu. Jurnal Pendidikan Dasar Islam, 5(1).

Unang W. (2018). Implementasi Literasi Media dalam Proses Pembelajaran Pendidikan Agama Islam dan Budi Pekerti. Edukasi Islami: Jurnal Pendidikan Islam, 07(2). hlm. 230. 
Usman. (2018). Upaya Meningkatkan Kompetensi Guru Binaan Dalam Proses Pembelajaran Melalui Supervisi Akademik Di Kelas Semester Satu Tahun Pelajaran 2017/2018 SD Negeri 39 Mataram. JISIP, 2(1).

Zulfikar., \& Yusrizal, S. I. (2017). Supervisi Akademik Oleh Kepala Sekolah dalam Meningkatkan Kompetensi Profesional Guru SD Negeri 2 Calang Kabupaten Aceh Jaya. Jurnal Magister Administrasi Pendidikan, 5(3). 